\title{
Self Efication in Interpreting as a Teacher in Indonesia
}

\author{
Agung Listiadi ${ }^{1, *}$ Rochmawati $^{1}$
}

\author{
${ }^{1}$ Universitas Negeri Surabaya \\ "Corresponding author. Email: agunglistiadi@unesa.ac.id
}

\begin{abstract}
The purpose of this study is to see how perceptions of teaching, self-efficacy, and learning management programs affect people's desire to become teachers. The goal of this study is to look into the impact of teacher perceptions, self-efficacy, and other factors. and learning management towards the interest in becoming a teacher. Students who are interested in becoming teachers, especially in the field of accounting are still few. One of the factors influencing students' interest to become accounting teachers is perceptions about the teaching profession, self-efficacy and field experience programs. They will try harder to accomplish tasks, tackle problems, and achieve achievement if they are interested in being a teacher and have a high feeling of self-efficacy. This is a quantitative study employing questionnaires and documentation as data gathering approaches. In this investigation, a saturated sample was used. Multiple linear regression analysis was employed in this study's data analysis. Perceptions of the teaching profession, self-efficacy, and learning management programs all influence motivation in becoming a teacher, according to the findings.
\end{abstract}

Keywords: Perception of the teaching profession, Self-Efficacy, learning management, Interest in becoming a teacher, Accounting.

\section{INTRODUCTION}

Education in the era of globalization is expected to create quality human resources and character so that they can compete globally. This is because education is a forum for manpower development, can be to increase employment and also to obtain certain status in life in the community [1]. One of them is by holding the development of activities in the fields of education. To produce a quality education, it must be balanced with professional educators or teachers. The role of teachers is very important in the field of education because teachers develop learning in talent and potential for students so that they become graduates who have quality human resources. Choosing a role to be a teacher is not an easy thing for everyone to do because a teacher not only conveys learning in class but also guides and shapes learners' character [2]. Interest in the teaching profession can be seen from the constant tendency to pay attention to the teaching profession, there is a sense of liking and delight in the teaching profession, gaining pride in the teaching profession, there is a sense of interest in the teaching profession and manifested through activities related to the teaching profession [5]. This difference in perception can be traced to differences in experience, differences in personality, differences in attitudes or differences in motivation [6]. The intended student perception is the student's perception of the teaching profession. Teacher professional perception is the process of using knowledge in interpreting stimuli (stimuli) by the sensory devices related to the teaching profession, or it can be interpreted as a process of the meaning of the teaching profession in a person. How a job can be said as a profession if it meets the criteria of the main source of income, the largest outpouring of work time, special skills and competencies, special education and training, Standardization and organization, and professional code of ethics [4]. High student perceptions of the teaching profession will lead to an interest in being a teacher in students, conversely, negative perceptions will make students uninterested in becoming teachers.

\section{LITERATURE REVIEW}

\subsection{Teacher Professional Perception}

The term perception is often referred to as views, images, or assumptions because in perception there is a person's response to a thing or object. Perception has many meanings, according to [10] states that the human analysis refers to the process that involves the input of signals or information into the human brain while maintaining a relationship with their 
surroundings. Teacher professional perception is the process of using knowledge in interpreting stimuli (stimuli) by sensory devices related to the teaching profession, or it can be interpreted as a process of the meaning of the teaching profession in a person [11]. The existence of different perceptions about the teaching profession in students can lead to liking or disliking the teaching profession and will affect the interest of students to become teachers to students.

\subsection{Self-efficacy}

According to [8] states that self-efficacy is a belief that can process and take action to achieve goals that are closely related to self-concept which has an important role in academics to achieve the success that someone has determined. According to [9], stating that self-efficacy is a belief in their ability to overcome problems and obstacles that prevent them from achieving a goal. Weak experience will weaken his beliefs as well. Individuals who have a strong belief in their abilities will be steadfast in trying to put aside the difficulties faced and not easily overwhelmed in the face of difficulties [13]. With this experience, selfconfidence will arise in a person that he can realize in achieving certain performance.

\subsection{Learning Management Program}

Learning Management Program is a subject that must be taken by students Through this course, students are allowed to explore and strengthen competence as prospective teachers in the field of study/facilitator. According to Webber [12], learning experiences during this course support the achievement of competencies. This course also deals with strengthening personality as a teacher/facilitator, as well as a variety of learning experiences that make it possible to develop professionalism sustainably for students. Social competence is the ability of teachers to communicate with components of the school community and the surrounding environment, including communicating and interacting effectively with students, fellow educators, education personnel, parents/guardians of students, and surrounding communities [7]. Professional competence is the mastery of learning material widely and deeply, including mastering material related to the field of study and mastering the structure and methods of science [4].

\subsection{Interest in becoming a teacher}

[5] Interest is defined as a sensation of preference and interest in an item or action, without someone telling and acknowledging a relationship between oneself and something external to oneself. Interest is a sensation of liking and interest in a subject or activity that occurs without someone asking or forcing it, and it causes you to pay more attention to it.
Meanwhile According to [3] argues that interest as a source of motivation that encourages people to do what they want is given freedom of choice. From the opinion of some experts, it can be concluded that the notion of interest is a sense of attraction towards something and a feeling of pleasure so that it is interesting to keep looking for information and eventually it will reach a desired and coveted point. Being an accounting teacher is a talent because being a teacher is not an easy job.

\section{METHOD}

\subsection{Design research}

This type of research is quantitative research. Quantitative research is a research method that presents data in the form of numbers and uses statistical analysis intending to test the hypotheses that have been set. Quantitative research in this study is intended to find out and analyze between independent variables consisting of Teacher Professional Perception, Self-Efficacy, and Learning Management Programs.

\subsection{Respondent}

A population is an object or subject determined by a researcher to be studied and then drawn to the conclusion that the provisions have special characteristics and qualities depending on the researcher. The population in this study were students of the Accounting Education Study Program in Indonesia. In this study, the sample taken was by using Saturated Sampling, with 80 respondents.

\subsection{Data Analysis}

In research, analysis techniques are used to answer a study's issue formulation or testable theories that have been generated. Multiple regression results indicate the direction of the link between the dependent variable and the independent variable as well as the intensity of the association between more than two variables.

\section{RESULTS AND DISCUSSIONS}

\subsection{Results}

The t-test in the research aims to test and find out the partial significance of each independent variable. In this study, the independent variables consist of perceptions of the teaching profession, self-efficacy, and learning management programs on dependent variables, namely the interest in becoming an accounting teacher. Probability figures serve as the foundation for t-test decision-making. $\mathrm{H}_{0}$ is rejected and $\mathrm{Ha}$ is accepted if the probability of the analytical result is less than 0.05 . The t-test findings are shown in Table 1 based on the hypothesis testing. 
Table 1 Result of t-test

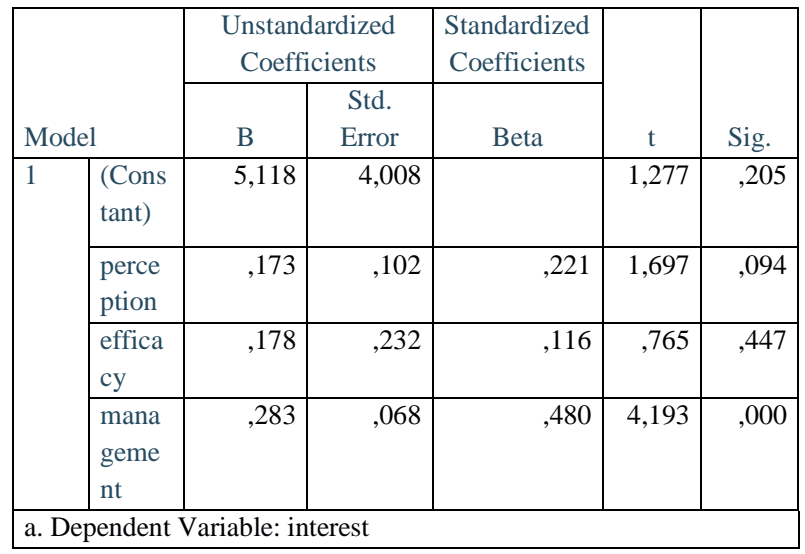

The influence of the perception of the teaching profession on the interest in becoming an accounting teacher of Accounting Education Study Program Faculty of Economics. In this study, the t-test value of the variable perception of the teaching profession was 1.697, with a significant value of 0.094. Because the significance level is greater than $0.05, \mathrm{H} 0$ is accepted and $\mathrm{Ha}$ is rejected. This demonstrates that a student's motivation in becoming a student accounting instructor is unaffected by a different opinion of the teaching profession. The Effect of Self-Efficacy on the interest in becoming a student accounting teacher of 2015 Accounting Education Study Program Faculty of Economics. The t-test value of self-efficacy factors in this study was 0.765 , with a significant value of 0.447 . Because the significance level is greater than $0.05, \mathrm{H} 0$ is accepted and $\mathrm{Ha}$ is rejected. This demonstrates that the selfefficacy variable does not affect motivation in becoming a student accounting teacher. In this study, the t-test value of self-efficacy variables was 4,193 with a significant value of 0,000 . Because the significance level is less than $0.05, \mathrm{H}_{0}$ is rejected whereas Ha is approved. This demonstrates that the learning management program variable has a considerable effect on students' desire in becoming student accounting teachers. The F test in the study aims to test and find out whether all independent variables have the same effect on the variables of testing, knowing, and analyzing the effects simultaneously of the independent variables, namely the perception of the teaching profession, selfefficacy, and learning management programs on the dependent variable, namely the interest in becoming an accounting teacher. The probability statistics are used to make the $\mathrm{F}$ test choice in this study. If the likelihood of the analytical outcome is $\leq 0.05$ then $\mathrm{H} 0$ is rejected and $\mathrm{Ha}$ accepts. $\mathrm{F}$ test results in this study can be seen in Table 2 .

Table 2. Result of F-Test

\begin{tabular}{|l|l|r|r|r|r|c|}
\hline \multicolumn{7}{|c|}{ ANOVA } \\
\hline \multirow{2}{*}{ Model } & $\begin{array}{c}\text { Sum of } \\
\text { Squares }\end{array}$ & df & $\begin{array}{c}\text { Mean } \\
\text { Square }\end{array}$ & \multicolumn{1}{c|}{ F } & Sig. \\
\hline \multirow{2}{*}{1} & Regression & 1241,614 & 3 & 413,871 & 30,604 &, $000^{\mathrm{b}}$ \\
\cline { 2 - 7 } & Residual & 1027,773 & 76 & 13,523 & & \\
\cline { 2 - 7 } & Total & 2269,387 & 79 & & & \\
\hline \multicolumn{2}{|l|}{ a. Dependent Variable: interest } \\
\hline \multicolumn{2}{|l|}{ b. Predictors: (Constant), management, perception, efficacy } \\
\hline
\end{tabular}

The t-test value of self-efficacy variables in this study was 4,193 , with a significant value of 0,000 . H0 is refused since the significance threshold is less than 0.05 , but Ha is approved. This reveals that the variable of the learning management software has a significant impact on students' intention to become student accounting teachers. As a result, the study concludes that one's perception of the teaching profession, selfefficacy, and concurrent learning management systems all have a substantial impact on one's desire to become an accounting teacher. In a research, the coefficient of determination (R2) assesses how well the independent variable regression model, which includes perceptions of the teaching profession, selfefficacy, and learning management programs, explains the dependent variable, which is interest in becoming an accounting teacher. The results of the coefficient of determination test can be seen in the following Table 3.

Table 3. Coefficient of Determination

\begin{tabular}{|l|c|c|c|c|c|}
\hline & & & $\begin{array}{c}\text { Adjust } \\
\text { ed R } \\
\text { Squar }\end{array}$ & & \\
\hline & & & Std. Error of \\
Model & $\mathrm{R}$ & R Square & e & Durbin- \\
the Estimate & Watson \\
\hline 1 &, $740^{\mathrm{a}}$ &, 547 &, 529 & 3,67741 & 2,003 \\
\hline a. Predictors: (Constant), management, perception, efficacy \\
\hline \multicolumn{7}{|l|}{ b. Dependent Variable: interest } \\
\hline
\end{tabular}

Based on table 3 above, the research results obtained a value $\operatorname{Adjust} R$ square $\left(\mathrm{R}^{2}\right)$ of 0,529 . This matter shows that the coefficient of determination $\mathrm{R} 2$ value that is the variable perception of the teaching profession, selfefficacy, and learning management programs contributed $52.9 \%$ to the interest in becoming an accounting teacher. While the remaining $47.1 \%$ is influenced by other variables not examined in this study. The findings of this study show that perception of the teaching profession, self-efficacy, and learning management programs all have a substantial influence on accounting students' interest in the 2015 
Accounting Education Study Program Faculty of Economics.

Based on the results of data analysis using multiple linear regression analysis, the ANOVA test table or the F test obtained a probability value of 0000 . Because the probability value is smaller than 0.05 , it is reasonable to conclude that the three independent factors all impact the desire to become an accounting instructor concurrently. This is also corroborated by the R square (R2) value of 0.529 , which indicates that variables such as teacher professional perception, self-efficacy, and learning management programs influence 52.9 percent of interest in becoming an accounting teacher. Other variables not stated or investigated in this study effect the remaining 47.1 percent. as a result.

\subsection{Disscussion}

The t-test result for the teacher professional perception variable in the research was 1.697 with a significant value of 0.094. Because the significance level is less than 0.05, $\mathrm{H} 0$ is accepted while $\mathrm{Ha}$ and $\mathrm{M}$ are rejected. And this can be interpreted that the variable perception of the teaching profession partially does not significantly influence the interest in becoming an accounting teacher. The positive value of the regression coefficient means that the influence that arises in this study is unidirectional, where if the perception of the teaching profession in students is good the interest in becoming a student accounting teacher will also increase and vice versa. Special indicators of expertise and competence have the biggest factor load with good category. Students are of the view that a profession requires special expertise and competence. Students have a high perception, having the view that, a profession must have an organization and rules as outlined in the professional code of ethics. As a professional accounting teacher, dedicated to guiding students to educate the nation's life, accounting teachers must implement all government policies in the field of education and adhere to the code of ethics of the accounting teacher profession. And the variable perception of the teaching profession does not significantly influence the interest in becoming an accounting teacher. Many students do not have an interest in becoming accounting teachers. So, the second hypothesis that reads: There is an effect of partial perception of the teaching profession on the interest in becoming an accounting teacher is declared rejected. Thus, it can be concluded that the perception of the teaching profession partially has a positive and not significant effect on students' interest in becoming teachers.

The results of the t-test for self-efficacy variables in this study obtained a value of 0.765 with a significance value of 0.447 . Because the significance value is more than 0.05 , therefore, Ho is accepted and $\mathrm{Ha}$ is rejected. And this can be interpreted that partial self-efficacy variables do not significantly influence the interest in becoming an accounting teacher. If students have high self-efficacy, it will increase students' interest to become accounting teachers. Students with high self-efficacy will direct their thoughts and effort harder on matters related to interest in becoming accounting teachers than students with low selfefficacy, accomplish more difficult work, achieve job targets than students with low self-efficacy. But it can also be improved by trying on difficult jobs and setting higher targets. The strength indicator has the most influence on either category. The high self-efficacy of students can be seen from how much the ability to face challenges in work and how much the ability to withstand the problems that occur in his work. Students who have an interest in becoming a teacher have real and positive influences that are few. So that the second hypothesis which reads: There is an effect of partial perception of the teaching profession on the interest in becoming a student accounting teacher was declared rejected. Thus, it can be concluded that partial self-efficacy does not have a positive and significant effect on students' interest in becoming teachers. In this study, the T-test findings for learning management program variables received a value of 4.193 with a significant value of 0,000 Because the significance level is less than $0.05, \mathrm{H} 0$ is rejected whereas Ha is approved. And this might be read to mean that the variable learning management program has a major impact on the desire to become an accounting instructor. Based on the results of the data description of learning management program variables, it can be seen that experience, in students included in the high category, shows that the influence of experience has a very important role in the interests of becoming a teacher. The higher the influence of experience, the higher the interest in becoming an accounting teacher. the student is in teaching, the higher the student's interest in becoming a teacher will be.

\section{CONCLUSION}

Based on the results of research and discussion conducted by researchers, it can be concluded that the perception of the teaching profession, self-efficacy, and learning management programs simultaneously affect the interest in becoming a teacher. The perception of the teacher profession partially does not affect the interest in becoming a teacher. Partial self-efficacy does not affect the interest in becoming a teacher. The learning management program partially influences my interest in becoming a teacher. 


\section{AUTHORS' CONTRIBUTIONS}

The author's contribution in this research is to synthesize the self-efficacy of interest in becoming a teacher in vocational schools. Professional competence is a good category. That means students have professional competence and good experience, for example in mastering material related to the field of study. The fourth indicator of social competency with good categories. That means having professional competence and good experience for example being able to communicate and get along with the surrounding community.

\section{ACKNOWLEDGMENTS}

This research was supported by Surabaya State University. We thank our colleagues from Economic Education Faculty who provided insight and expertise that greatly assisted the research. We would also like to show our gratitude to the Indonesia Economic Education Teachers Association for sharing their pearls of wisdom with us during this research

\section{REFERENCES}

[1] Arshad, Hariom. 2014. Impact of Globalization on Education: A Study with Reference to Slum Dwellers in Agra, India. Journal of Education \& Social Policy, 1 (2). 66-73.

[2] Agir Meral Sert. 2019. The Effect of Perceived Teacher Behaviors on Students' Self-Esteem and Attitudes Towards Learning. Journal of Education and Learning, 8 (5).203-218.

[3] Bakar Rahim, N. I., \& Hamza, R. (2014). Teaching as A Career Choice: A Discriminant Analysis of Factors as Perceived by Technical And vocational Education (TVE) Student Teachers in Malaysia. Middle-East Journal of Scientific Research, 19, 69-75.

Https://Doi.Org/10.5829/Idosi.Mejsr.2014.19.Ic mrp.11.

[4] Ball, D. L. (2000). Bridging practices: Intertwining content and pedagogy in teaching and learning to teach. Journal of Teacher Education, 51, 241-247.
[5] Eren Altay. 2012. Prospective Teachers' Interest in Teaching, Professional Plans about Teaching and Career Choice Satisfaction: A Relevant Framework? Australian Journal of Education, 56(3), 303-318.

[6] Kahu Ella, Karen Nelson, and Catherine Picton. 2017. Student interest as a key driver of engagement for first-year students. Journal of Student Success, 8 (2). 55-66.

[7] Lampert, M., \& Graziani, F. (2009). Instructional activities as a tool for teachers and teacher educators' learning. Elementary School Journal, 109(5), 491-509.

[8] Mambwe Robinson. Chanda. P. Chishimba, Peter. C. Manchishi. 2019. Student Teacher Preparation and Self-Efficacy Beliefs about Inductive Teaching-Learning Methods in Primary Colleges of Education, Zambia. International Journal of Education and Research, 7 (2). 179-196.

[9] Rodríguez Susana, Bibiana Regueiro, Rebeca Blas , Antonio Valle , Isabel Piñeiro and Rebeca Cerezo. 2014. Teacher self-efficacy and its relationship with students' affective and motivational variables in higher education. European Journal of Education and Psychology, 7 (2). 107-200.

[10] Tanang Hasan, Baharin Abu. Teacher Professionalism and Professional Development Practices in South Sulawesi, Indonesia. Journal of Curriculum and Teaching, 3 (2). 25-42.

[11] Tarman Bulent. 2012. Prospective Teachers' Beliefs and Perceptions about Teaching as a Profession. Educational Sciences: Theory and Practice, 12(3), 1-24.

[12] Webber lennie Scott - Roger Konyn dyk Marilyn Denison. 2019. POE: Understanding Innovative Learning Places and Their Impact on Student Academic Engagement-Index 6-8 'Alpha' Survey Developments. Journal of Education and Learning Archives, 8 (5). 31-56.

[13] Yoo Julia H. 2016. The Effect of Professional Development on Teacher Efficacy and Teachers' Self-Analysis of Their Efficacy Change. Journal of Teacher Education for Sustainability. 18(1). 84-94. 